\title{
Legislativní změny ve školství 2020/2021 \\ a jejich věcné dopady do praxe škol
}

\author{
Mgr. Ivana Blažková, MŠMT
}

\section{Abstrakt}

Představení legislativních úprav školských právních předpisů a jejich účel z pohledu zákonodárce. Vybraná ustanovení školského zákona a vyhlášky o vzdělávání žákủ se speciálními vzdělávacími potřebami a žákủ nedaných, konkrétní uplatnění v praxi.

\section{Klíčová slova}

školský zákon, ředitel, škola, pedagogická intervence, žák, školské poradenské zařízení

\section{Úvod}

Cílem je odborníky z pedagogické praxe informovat o legislativních změnách, aktuálně účinných a v praxi již realizovaných tak, aby byly promítnuty do každodenní práce se studenty či publikační činnosti a dalších výstupů dle profesního zaměření.

\section{Současný stav poznání}

Východiskem je zákon č. 561/2004 Sb., ve znění pozdějších předpisů (školský zákon) a vyhláška č. 27/2016 Sb. o vzdělávání žáků se speciálními vzdělávacími potřebami a žáků nadaných, ve znění pozdějších předpisů.

\section{I. zákon č. 561/2004 Sb., ve znění pozdějších předpisů}

\section{a) Dočasný ředitel}

- §166 odst. 10 školského zákona:

Pokud škola nebo školské zařízení veřejného zřizovatele nemá ředitele, může zřizovatel jmenovat ředitele školy na vedoucí pracovní místo bez konkursního řízení na dobu určitou do doby řádného jmenování ředitele. Zřizovatel vyhlásí konkursní řízení zbytečného odkladu. Dočasný ředitel je plnohodnotný ředitel (ale na krátkou dobu), vykonává všechny pravomoci a povinnosti bez omezení, musí splňovat všechny podmínky podle zákona.

- §166 odst. 11 školského zákona:

Pokud řediteli školy nebo školského zařízení veřejných zřizovatelů ve výkonu činnosti brání překážka v práci dlouhodobého charakteru, zejména uvolnění k výkonu veřejné funkce nebo rodičovská dovolená, může zřizovatel na základě jím vyhlášeného konkursního řízení jmenovat ředitele školy na vedoucí pracovní místo na dobu určitou po dobu překážky v práci ředitele, nejdéle však na 6 let; stejnou osobu je možné jmenovat opakovaně. Do doby jmenování ředitele podle věty první může zřizovatel jmenovat ředitele školy na vedoucí pracovní místo bez konkursního řízení. Šestileté období se řediteli prodlužuje o dobu, po kterou byl ředitel uvolněn pro výkon veřejné funkce (starosta, uvolněný radní, poslanec...). V jiných případech je ředitel/ředitelka uvolněn z funkce ředitele, ale neprodlužuje se funkční období (např. rodičovská dovolená -započítá se do běhu funkčního období). 


\section{b) Změny u maturitní zkoušky}

Zrušení zavedení povinné společné části maturity ze 3 předmětů, ale zachování současného stavu - možnost výběru mezi předměty (matematika - cizí jazyk). Společná část obsahuje pouze didaktické testy, zbytek je přesunut do profilové části. Má-li žák právo konat opravnou zkoušku nebo náhradní zkoušku (přesunuté dílčí zkoušky) bude konat opravnou nebo náhradní zkoušku profilové části. Došlo k zavedení Matematiky +, jedná se o nepovinnou zkoušku matematiky rozšǐrující (nyní existuje v rámci pokusného ověřování).

\section{c) Doplnění pravidel financování}

Byl zaveden účelový normativ podle \$161 odst. 7 školského zákona pro školy veřejných zřizovatelů. Ưčelový normativ se vyhlásí ve Věstníku, dochází k přímému financování bez žádosti ze škol, čímž dojde k administrativnímu zjednodušení. V návaznosti na to se ruší rozvojové programy.

\section{d) Novela od 1. října 2020 zavedla také}

Možnost omezit nebo zakázat použivání mobilních telefonů nebo jiných elektronických zařízení ve školách a školských zařízeních školním nebo vnitřním řádem, s výjimkou jejich používání v nezbytném rozsahu ze zdravotních důvodů.

Rozšíření možnosti použít neinvestiční výdaje (tzv. ONIV) i na dopravu na školní akce.

Právo zřizovat přípravné třídy základních škol i soukromým zřizovatelům. (Nutný souhlas MŠMT).

Zkrácené studium s výučním listem bude moci absolvovat i žák, který úspěšně dokončí 4. ročník maturitního oboru (dnes tak může učinit pouze pokud má maturitu).

\section{II. vyhláška č. 27/2016 Sb., ve znění pozdějších předpisů}

\section{a) Intervence ve vzdělávání}

Termín intervence pochází z latinského slova intervenire = zakročit, zasáhnout. Intervence znamená zásah proti/do nežádoucího jevu. V procesech vzdělávání je základním účelem intervence jejich optimalizace. Ve vztahu k individuálnímu žákovi je cílem intervence podpořit ho v dosažení takového vzdělání, které odpovídá jeho potencialitě.

\section{Intervence ve škole probíhá:}

v systému školy - v prostředí, v podmínkách a průběhu vzdělávání, vztahuje se ke všem žákům, cílem je eliminovat rizika, která ohrožují/znevýhodňují procesy učení a výuky - jde především o cílenou prevenci;

v procesech sociální interakce - v předcházení rizik ohrožujících sociální vztahy a chovánížáků; v přerušení a eliminaci faktorů narušujících otevřené sociální vztahy a interakci na horizontální i vertikální úrovni těchto procesů;

v procesech učení a výuky - v naplňování cílů učiva, ve vztahu k individuálnímu žákovi s potřebou cílené podpory v učení.

\section{b) Pedagogická intervence}

Smyslem pedagogické intervence v pojetí poradenské praxe je vyrovnávání př́ležitostí a podmínek při vzdělávání. Pedagogickou intervencí se dostává potřebným žákům intenzivnější podpora ze strany pedagogů k posílení jejich strategií v učení a k doplnění a procvičování problematických oblastí učiva; případně třídnímu kolektivu v situaci rizika působení sociálně patologických jevů. V praxi se tato podpora jeví jako forma doučování v počtu jednoho až šesti žáko̊, se zaměřením na již probrané, ale též aktuální učivo a vzájemné propojování.

Ve vztahu k chování žáka probíhá intervence převážně ve skupině. Jejím smyslem je posilování sociálních dovedností a kompetencí spolupráce v týmu a pochopení fungování vztahů v kolektivu.

Cílem předkládané právní úpravy je zefektivnění poskytování pedagogické intervence, které umožní reagovat pohotově na aktuální vzdělávací potřeby žáků a snížení administrativní zátěže škol, zákonných zástupců i ŠPZ.

Změna dále reflektuje další systémové změny v oblasti regionálního školství (změnu financování účinnou od ledna 2020, významné navýšení platů pedagogických pracovníků, zvyšování počtu nepedagogických pracovníků ve školách).

Předchozí právní stav byl př́činou zbytečně zdlouhavého administrativního procesu na straně škol a školských poradenských zařízení před vlastním poskytováním pedagogické intervence a neumožňoval reflektovat aktuální vzdělávací obtíže jednotlivých žáků a operativně na ně reagovat podporou již v počátku jejich ohrožení školním neúspěchem. 
Školy navíc neposkytovaly podpůrné opatření pedagogická intervence všem svým žákům, kteř́ dané podpůrné opatření objektivně potřebovali, ale pouze těm, kteří měli doporučení ŠPZ. Tento stav bylo nutné, s ohledem na spravedlivou saturaci potřeb žáků, změnit.

Pedagogickou intervenci upravil předkladatel nově tak, aby operativně, v momentě aktuální potřeby, vyrovnávala příležitosti žáků úspěšně dosahovat vzdělávací cíle i přes počáteční/přechodné/dlouhodobé znevýhodnění z důvodu nedostatečných příležitostí k učení (zejména sociálně znevýhodňující prostředí), vnějších vlivů (návrat ze zahraničí, časté změny školy, dysfunkční rodinné zázemí aj.), vývojových deficitů a opoždění (dílčí oslabení výkonu), zdravotního oslabení/postižení (dlouhodobá nemoc, závažné zdravotní problémy).

Na tuto podporu dosáhnou tedy aktuálněi ti žáci, kteří nejsou aktuálně klienty školského poradenského zařízení, nebyly jim ještě diagnostikovány speciální vzdělávací potřeby, ale přesto potřebují podporu ze strany školy.

Rovný př́stup k tomuto podpůrnému opatření je tedy zajištěn v plné míře, a to včetně žáků ze sociálně znevýhodněného či odlišného kulturního prostředí.

Přidanou hodnotou poskytování pedagogické intervence jako podpůrného opatření 1. stupně je rovněž flexibilita v organizaci, formě i délce poskytování této podpory podle potřeb žáků.

Právní úprava nestanoví podrobná pravidla pro organizaci pedagogické intervence, neurčuje minimální ani maximální délku pedagogické intervence, nestaví závazné limity počtu žáků ve skupině atd., škola přizpůsobuje parametry pedagogické intervence potřebám žáků.

Institut pedagogické intervence je po novele vyhlášky nově upraven samostatně v ustanovení § 4 a.

c) Financování pedagogické intervence

Financování pedagogické intervence je dalším systémovým krokem MŠMT navazujícím na reformu financování účinnou od 1. 1. 2020. Pro rok 2021 byl posílen celoroční normativ pro základní školy, což umožnilo odpovídající odměňování pedagogických pracovníků zajištujujicích od 1. 2. 2021 pedagogickou intervenci. Pro základní školy zřizované krajem, obcí nebo dobrovolným svazkem obcí byl posílen normativ průměrné roční výše osobních příplatků, odměn a cílových odměn pedagogických pracovníků. Pro základní školy ostatních zřizovatelů byl posílen normativ mzdových prostředků.

Finanční prostředky, které může ředitel školy využít k odměňování pedagogických pracovníků poskytujících pedagogickou intervenci, tak jsou součástí rozpočtu školy (právnické osoby) stanoveného na rok 2021 a budou i pro roky další.

Ve finálním návrhu novely vyhlášky je zachována možnost poskytovat toto podpůrné opatření všemi pedagogickými pracovníky školy s odpovídající kvalifikací. Organizace realizace pedagogické intervence a její personální zajištění je plně v kompetenci ředitele školy.

d) Závěr

Novela vyhlášky č. 27/2016 Sb. tedy cíleně směřuje k účelné podpoře vzdělávacích výsledků žáků se speciálními vzdělávacími potřebami v hlavním vzdělávacím proudu, minimalizaci rizika školní neúspěšnosti a maximální podpoře rozvoje jejich vzdělávacího potenciálu. To vše je podpořeno zajištěním systémového řešení financování přímo do rozpočtu škol.

\section{Závěr}

Výše uvedené novelizační změny reflektují aktuální potřebu praxe škol. Po ověření dopadu bude vyhodnoceno (cca po 2 letech).

\section{Literatura}

Sbírka zákonů

\section{Informace o autorech}

\section{Mgr. Ivana Blažková}

vedoucí oddělení předškolního, zájmového, speciálního a základního uměleckého vzdělávání MŠMT 